Management Dynamics

Vol. 23, No. 2: 243-254, 2020

Shanker Dev Campus

Doi: https://doi.org/10.3126/md.v23i2.35825

\title{
Impact of Corona Virus pandemic on Different sectors of Nepalese Economy
}

\begin{abstract}
Nirdosh Khanal*
ABSTRACT

Novel coronavirus (COVID-19) causing persistent drumbeat of positive tests and reported deaths across the globe, has created widespread crisis in Nepal as well. The crisis has already led into an economic and labour market shock, impacting both on demand and supply chain. Due to the outbreak of this deadly coronavirus, Nepal has started to suffer the most abrupt and widespread cessation of economic activity. The goal of this paper is to study the emerging and rapidly growing literature on the impact of COVID-19 on various economic and social sectors and to synthetize the insights emerging from a very large number of studies. This study summarizes the literature on the socio-economic consequences of corona virus and consequent lockdown imposed by government on Nepal. This study revealed that COVID-19 has negatively impacted macro economy of country lowering national GDP, decreasing revenue collection, slowing economic growth rate, decreasing wage rate, price inflation and causing loss of employment opportunities. The study showed that almost every sector of socio-economics has been slowed down that adversely effect on country's economy. The effect are identified on Remittance, Labour and Employment, Tourism, Education and Agriculture (Dairy, vegetables and Poultry). The uncertain impact of the COVID-19 pandemic on Nepal's social economy will magnify depending on how events unfold on three fronts; i) its dependence on tourism, trade, and foreign employment and the consequences that will propagate through the services and industrial landscape; ii) if or when the spread of the pandemic overwhelms a grossly inadequate heal th infrastructure and antivirals or vaccine become available and iii) Nepal's heavy geo-economic reliance on India and China, and the nature of contagion in those countries.
\end{abstract}

Key words: Covid-19, Remittance, Labour and Employment, Tourism, Education and Agriculture

\section{Introduction}

A novel coronavirus named severe acute respiratory coronavirus 2 (SARS-CoV-2) was first identified in a seafood market in Wuhan City, Hubei Province in China, at the end of 2019 (Zhu et al., 2020). The contagious respiratory illness caused by this novel coronavirus is called coronavirus disease 2019 or, in short, COVID-19 (Wu et al., 2020). On 30 January 2020, the World Health Organization declared a novel coronavirus 'COVID-19' a matter of public health emergency of international concern. In February of 2020, with the first death from COVID-19 in France and a steep increase of positive cases in Italy, the coronavirus pandemic became a matter of significant concern in Europe, the United States, Australia, Asia and on to

* Lecturer, Tribhuvan Multiple Campus Tansen, Palpa 
Africa. (Klonowska, 2020). This deadly novel coronavirus continues to wreak havoc on daily life around the globe.

\section{Present Scenario of Covid-19}

As reported on $13^{\text {th }}$ Dec 2020 on worldometer.info 72,641,016 total cases, and 1,618,822 total death cases till date. Among the world, the USA has recorded top rank in both total death cases and total infected cases by $16,737,267$ and 306,459 respectively, and India is in the second rank.

Figure 1: Total cases of Covid-19 till Dec 10, 2020

\section{Total Cases}

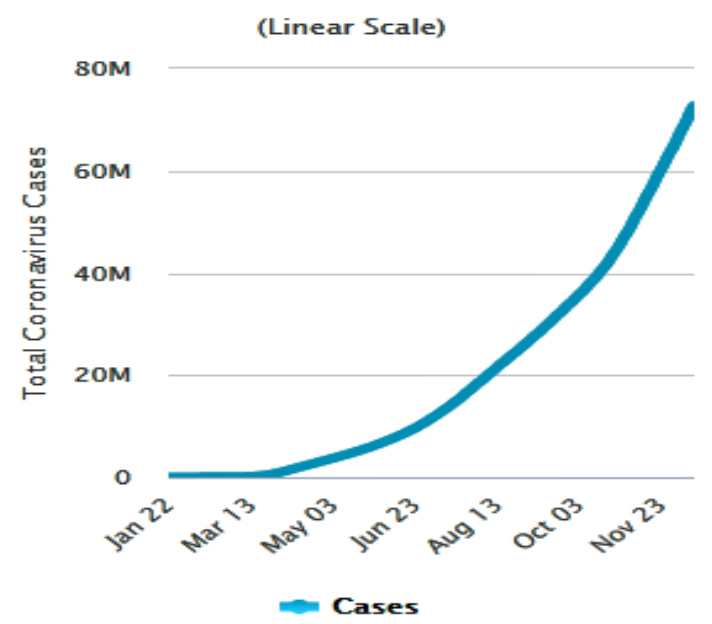

Source: Worldometer.info

Figure 2: Total Death of Covid-19 till Dec 10-2020

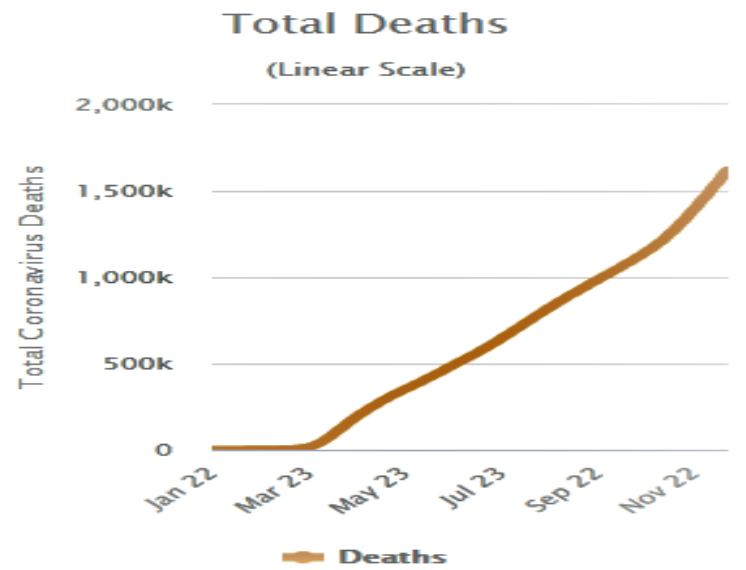

Source: Worldometer.info 


\section{Covid-19 in Nepal}

On 13 January, a 31-year-old Nepali student of Wuhan University, who had returned home on 5 January, was admitted with mild symptoms (Bastola et al., 2020). No any new cases were reported in February, a second case of COVID-19 was seen on 23 March (The Kathmandu Post, 2020). With a slow start, the total confirmed cases reached to 57 by April. Until this article was prepared (10 December), Nepal is in $40^{\text {th }}$ place among all the countries across the globe with more than 248,423 total cases resulting in different physical, socioeconomic and psychological impacts.

Figure 3: The number of COVID-19 infected cases in Nepal (as per 10 December 2020).

\section{Total Cases}

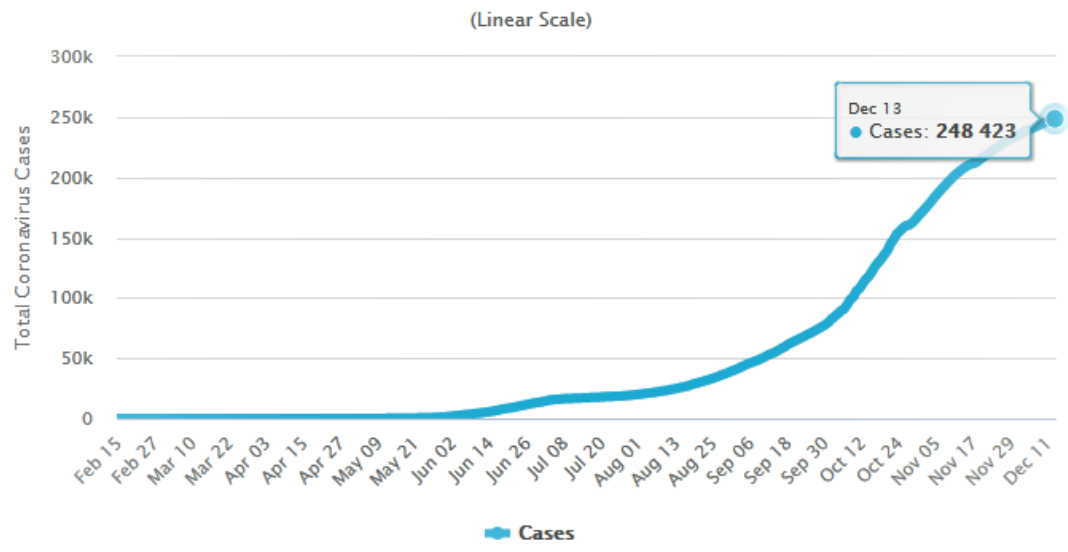

Source: Worldometer.info

Figure 4: The number of COVID-19 death cases in Nepal (as per 10 December 2020).

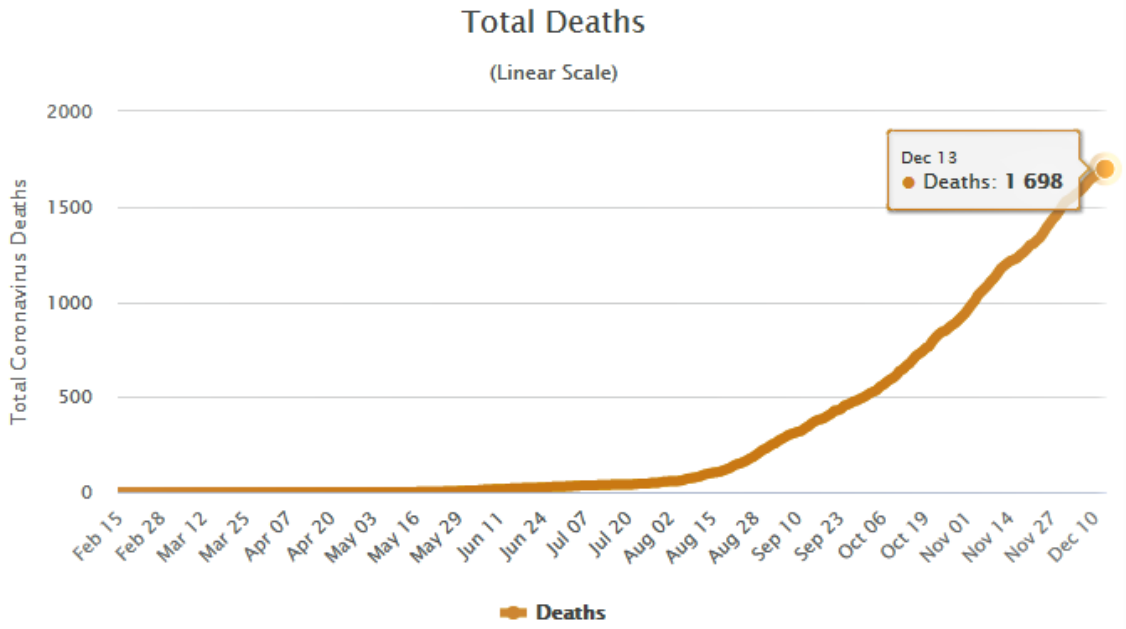

Source: Worldometer.info 


\section{Impact of COVID-19 lockdown}

Lockdown is considered to be an effective measure in slowing the spread of this pandemic coronavirus around the globe (Flaxman et al., 2020). To further stop the spread of the virus, many countries are currently in some degree of lockdown and enforcing strict quarantine measures. Until then, extreme social distancing is pretty much the only intervention available to keep healthy individuals spaced from each other. Even in the best-case scenario, coronavirus vaccine development may take 12-18 months (The New York Times, 2020)

\section{Macroeconomic impact}

The GDP growth is a major indicator of the macroeconomic impact of any type of fallout either economic or otherwise. In our case, the COVID-19 pandemic can be considered as a major health shock that has an implication on government resource allocation. This is because the government has to prioritize resources in the health sector to respond effectively to contain the spread of COVID-19. On the other hand, the government has to bring about various economic packages to address the need of the sectors affected by the lockdown. Nepal Labour Force survey (2017/18) shows that 85 percent of the labour force are informally employed in the country that includes all working in informal sector as well as those in the formal sector who are not receiving minimum basic benefits (CBS, 2017). Thus, people working in informal employment and business communities particularly cottage and small scale industries and tourism are mostly affected. This implication of resource allocation and the cessation of economic activities due to the country's lockdown will adversely affect the economic growth and other major macroeconomic variables.

Table 1: Growth in major macroeconomic variables from 2016/17 - COVID period

\begin{tabular}{|c|c|c|c|c|c|}
\hline Macroeconomic & & Annual & & $11 \mathrm{mo}$ & id-June) \\
\hline Indicator & 2016/17 & $2017 / 18$ & 2018/19 & 2018/19 & $2019 / 20$ \\
\hline $\begin{array}{l}\text { Real GDP at } \\
\text { producer's prices }\end{array}$ & 8.2 & 6.7 & 7.0 & - & 2.3 \\
\hline $\begin{array}{l}\text { Gross Fixed Capital } \\
\text { Formation/GDP }\end{array}$ & 31.4 & 34.6 & 33.7 & - & 28.1 \\
\hline $\begin{array}{l}\text { Gross National } \\
\text { Savings/GDP }\end{array}$ & 46.4 & 45.8 & 48.9 & - & 46.0 \\
\hline $\begin{array}{l}\text { Consumer Price } \\
\text { Inflation }\end{array}$ & 2.7 & 4.6 & 6.0 & 6.16 & 4.54 \\
\hline $\begin{array}{l}\text { Salary and wage Rate } \\
\text { Index }\end{array}$ & 13.4 & 6.8 & 9.1 & 9.54 & 7.48 \\
\hline Export Growth & 4.2 & 11.4 & 19.4 & 19.4 & 0.2 \\
\hline Import Growth & 28.0 & 25.8 & 13.9 & 17.3 & -15.3 \\
\hline $\begin{array}{l}\text { Remittances (Rs. in } \\
\text { billion) }\end{array}$ & 695.5 & 755.1 & 879.3 & 799.0 & 774.9 \\
\hline Revenue Growth (\%) & 26.4 & 19.3 & 20.0 & 19.1 & -13.1 \\
\hline $\begin{array}{l}\text { Expenditure Growth } \\
(\%)\end{array}$ & 40.2 & 30.7 & 0.1 & -4.7 & 6.5 \\
\hline
\end{tabular}

Source: Nepal Rastra Bank and CBS, 2020. 
As shown in table 1, the preliminary estimates of GDP growth plummeted to 2.3 percent as against the target of 8.5 percent in the current fiscal year (CBS, 2020). This indicate growth rate declined by more than 6 percent as compared to the target and nearly by 5 percentage $t$ as compared to the average growth rate of past three years. The effect of the outbreak of disease and subsequent lockdown has adversely affected the growth in real sectors. The economic growth is further expected to slow down since agricultural and industrial production is suffering due to supply disruptions (from lockdown) and reduction in domestic demand.

\section{Impact on Remittance}

The remittance; as a source of development funding is directly linked to international migration. As remittance provides a significant disposable income (acting as a substitute for earned income) against massive unemployment, illness, retirement, emigration, falling wages, and crop failure, coronavirus effect on remittance is disastrous. Nepal, 19th top remittance achiever in 2018, is popular for exporting the labor because of various reasons, for instance, civil war, political persecution, or economic hardships. Nepalese migrant workers are expected to send home only $\$ 7.4$ billion in 2020 which was 12 percent less from precoronavirus levels in 2019 as per the World Bank. Nepal Ratra Bank was more upbeat, saying that the World Bank had been conservative in its assumption, and that there would be no contraction in remittance this year. In the year 2019, Nepali expatriates sent back $\$ 8.2$ billion to their families.

As per the World Bank, the covid-19 pandemic related global slowdown and travel restrictions will also affect migratory movements, and this is likely to keep remittances subdued even in 2021. Additionally, Nepal Rastra Bank said the country would not see negative growth in remittance earnings in 2020, but the growth momentum might not last in 2021 as the global economy gets battered by the second wave of the Covid-19 pandemic. The growth in money transfers, despite an early prediction by different global agencies that Covid-19 may crash remittance globally including Nepal, indicates that the manufacturing sector has returned to its old self. According to the macroeconomic report of Nepal's central bank, the number of Nepali workers (institutional and individual-new and legalized) taking approval for foreign employment plunged by 99.2 percent in the review period. Likewise, the number of Nepalese workers (renew entry) taking approval for foreign employment decreased by 86.5 percent in the review period. The World Bank said that in India and Sri Lanka, remittances are projected to fall by about 9 percent in 2020 to $\$ 76$ billion and $\$ 6.7$ billion, respectively. In Pakistan, remittances would grow at about 9 percent, totaling about $\$ 24$ billion. In Bangladesh too, remittances are projected to grow at about 8 percent to around $\$ 20$ billion.

\section{Impact on Labour and Employment}

The economic impact of the COVID-19 pandemic brought by lockdown measures is idiosyncratic across sectors. The demand for essential goods, such as food and medicine, has increased sharply while demand for non-essentials has declined sharply. On services, demand for health care has increased rapidly whereas that for hotels, tourism and travel, among others, has collapsed. There have been severe disruptions to the supply chain as a 
result of restricted mobility of transport and labour. According to the NRB's annual report, the contribution of agriculture, forestry and fishing, industry and the service sector to GDP is 27 percent, 15.2 percent (of which manufacturing is 5.6 percent and construction is 7.8 percent), and 57.8 percent (of which hotel and restaurant is 2.05 percent) respectively for 2018/2019. The share of those sectors' contributions to GDP does not correspond to their shares of employment. Agriculture has the highest share of employment at 21.5 percent, followed by wholesale/retail and repair. Manufacturing and construction follow, at 15.1 percent and 13.8 percent, respectively. Sectors such as accommodation and food services (which have direct connections to tourism) and manufacturing are receiving first attention as the most impacted sectors. However, it is important not to ignore agriculture, construction, and wholesale and retail. In terms of the proportion of establishment in the country, wholesale and retail has the highest share of 53.9 percent and employs 17 percent of the workforce.

The economic impact of this lockdown has been immediate. Domestic and international trade has substantially slowed; supply of goods and services has plunged. The ADB estimates that the economic loss in industry ranges from NPR 1.7 billion to NPR 4.2 billion, while for the service sector the economic loss ranges from NPR 5.7 billion to NPR 9.98 billion. Estimated economy-wide loss ranges from NPR 8.5 billion to NPR 16.9 billion (ADB, 2020).

Figure 5: Unemployment rate of Nepal from 1999-2020

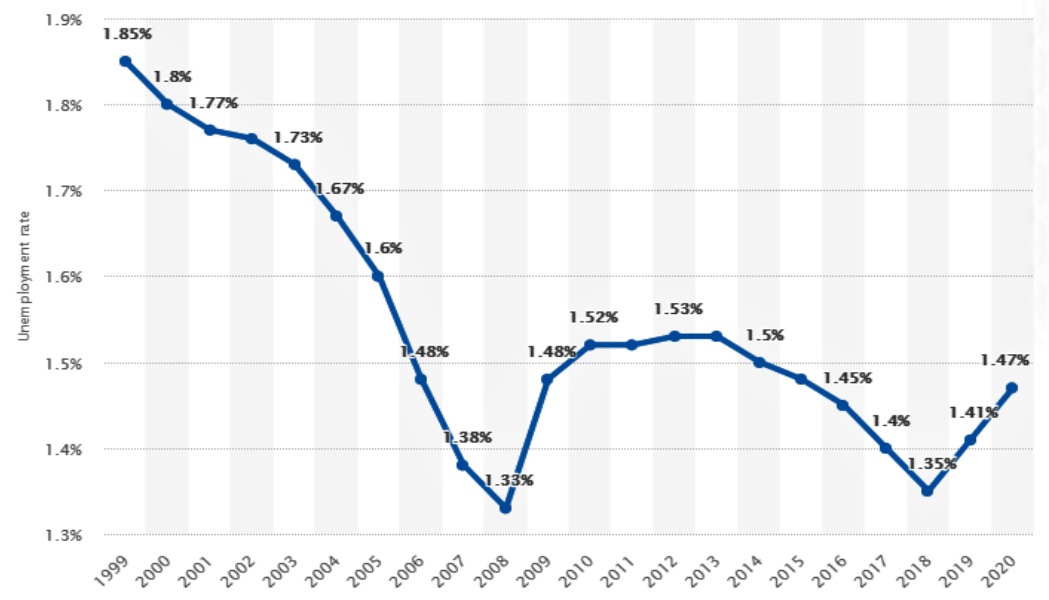

Source: Statistica, 2020

The trend of unemployment rate in Nepal shows decrease in the unemployment rate after 2013/14 because of stability in country political changes. But the line trend shows hike in unemployment rate after covid-19 crisis began on 2019. However there are no estimates of loss of employment in the affected sectors in these reports due to lack of data at regular intervals about job creation and loss in Nepal, difficulty for employers in Nepal to get rid of 
their workers due to, for example, labour laws and strong presence of labour unions, and lack of provision of unemployment benefits.

\section{Effect on Tourism}

Nepal's diverse landscape, people and cultural heritage make it an attractive - if still underutilized - tourist destination. In 2019, tourism contributed to 4 percent of GDP and employed five percent of the workforce in accommodation and food services. Nepal earned foreign currency worth $\$ 651$ million dollars from foreigner travelling to Nepal in 2018/2019 (mid-July), while tourism receipts saw a growth of 12 percent to $\$ 471$ million in the first eight months of 2019/2020 (mid-March) (NLFS, 2018). Earnings from foreign tourists accounted for 72 percent of the total value of merchandise export, a quarter of the total value of goods and non-factor services and fve percent of total foreign exchange earnings for Nepal in 2018 (DoT, 2019). Nepalese spent $\$ 383$ million travelling abroad in 2018/2019 (mid-July), while in the first eight months of the current fiscal year, spending abroad decline by a 20.8 percent to \$219 million (Nepal Rastra Bank, 2020). Despite reaching a historically high headcount of 1.2 million in 2019, this year tourist arrivals declined by two percent in January, one percent in February and over 73 percent in March. In terms of arrivals by month, October/November followed by February/March, are considered to be peak seasons in the industry (DoT, 2019) when Nepal typically receives most tourists.

The Government of Nepal launched Ghum Phir Year in 2016 to promote domestic tourism. The government planned to celebrate the year 2020 as Visit Nepal Year 2020, with a target of welcoming two million foreign tourists. This was accordingly with the 15th five-year plan in which the government had set an ambitious target of attracting 3.5 million foreign tourists by 2025 and generating $\$ 2$ billion in revenues. The COVID-19 pandemic has created uncertainty, halted travel and tourism, and has put the jobs of more than five percent of working Nepalese at risk. The government has taken initiatives that affect the tourism sector. For instance, Nepal stopped issuing on-arrival visa and online approval of visas to tourists on 12 March 2020. How quickly the tourism sector in Nepal will recover from the COVID-19 crisis is a function of domestic policies, promotional activities and the global health and economic situation, most notably in China, India, USA and Europe - Nepal's top sources for tourists. But with international travel restrictions, fear of COVID-19 and falls in discretionary income, spending on travel and tourism is likely to decline even after restrictions are lifted.

Low tourist earnings coupled with falling remittances are likely to lead to dwindling foreign exchange reserves, which is bad news for an import-dependent country. This can immediately strain the country's balance of payments, necessitating support from the IMF. Nepal aimed to earn $\$ 2$ billion from tourism receipts under the Visit Nepal Year (VNY) 2020 campaign from two million tourists that spent $\$ 75$ dollars a day. More importantly, with the travel ban imposed during March and April - the two months that Nepal receives a significant share of tourists - loss of earnings is likely to be more pronounced. One silver lining from this pandemic in Nepal is the possibility that domestic tourism might pick up greater momentum once the lockdown is lifted. As foreign countries have put tight travel restrictions in place 
and with fear of COVID-19 still looming large, Nepalese who would have otherwise visited foreign countries might have to make do with taking holidays within Nepal.

\section{Impact on Education}

The action of the government of Nepal to close all educational institutions, postponing of all national level examinations and prohibiting the gathering of more than 25 people together led to an outflow of more than 300,000 people from Kathmandu valley. Perceiving the village environment as pure, free from germs and contamination, and unlikely to get coronavirus might have led to the surge in the out flux of people. The drastic increase in new infection rates, lesser tests, increased media reporting and death tolls have increased public anxiety. The absence of clear messages and the desire for facts have heightened fear among the public and propelled them to seek information from less reliable portals (Rubin \& Wessely, 2020). The current lockdown has imposed multiple restrictions on research as research laboratories have been closed, and scientists and researchers are working from home, limiting recruitment in studies. According to the World Bank (2020a), the COVID-19 pandemic has caused more than 1.6 billion children and youth in 161 countries to be out of school, which is close to $80 \%$ of the world's enrolled students. Similarly, Parents have experience increased pressure to work from home, to keep their work running and to take care of schooling children at home at the same time, while caregiver resources including grandparents and the wider family have been restricted (Fegert et al., 2020). With the unprecedented lockdown, most parents have worries about child's education and their future as the school and college education has been halted until further notice. The Government of Nepal though has decided to introduce a digital education system to continue the teaching learning process, and this has further burdened parents with the load of school fees and online internet fees. But, this turn out to be further stressful for parents with low income who have to struggle for daily wages and do not have proper internet access, as it compromises the learning needs of their children. While Nepal can boost inexpensive, accessible and familiar resources such as radio networks, television broadcasting and social media for remote learning, it is important to assess the sustainability of its own existing resources, and checking the possibilities before deliberately imposing them on academic institutions and the public.

\section{Impact on Agriculture}

The agricultural crops, livestock and fisheries are not outside the impact of COVID-19. Being an agricultural Nation, the travel restriction and lockdown have affected each and every stage of the food supply chain, including food production and distribution in Nepal. Moreover, Farmers are compelled to dump vegetables and milk after a significant decrease in supply and closure of processing companies and proper markets (Poudel et al., 2020). This has led to sudden price hike, black marketing and shortage of products in the local markets. While the government is urging people to follow quarantine and limiting gathering of people, millions of farmers have to gather together to sow food and cash crops in Nepal with the arrival of the monsoon. The current lockdown measures might help the government to defeat this virus, but if the patterns of small-scale planting, harvesting and distribution continue to be disturbed, hundreds of thousands will lose their livelihoods, and the whole nation could 
slip into deep food insecurity. Therefore, the government should take effective measures to control the pandemic without disturbing the food supply chain and considering the food security of their nation.

\section{Impact on Dairy}

Dairy products contributing about 3.3 percent to GDP, represent around 12.4 percent of the agriculture sector (CBS, 2018). Comparison of the first nine months of FY 2018/2019 and 2019/2020 show that export of these items has been drastically reduced due to COVID-19. The foreign dependency on dairy products is significant, because Nepal imported $\$ 7.35$ million - four times more than the export in FY 2018/19 (DoC, 2019). The country's shutdown has caused a loss of about 80 percent, amounting to $\$ 30$ million, in the privately-owned dairy industry, due to fall in consumption and transport disruption. The market has contracted sharply due to the closure of restaurants, hotels and food outlets, and along with the mass migration of people from urban to rural areas has directly impacted the livelihoods of 0.5 million farmers and 10,000 staff who depend on the industry for employment. The difficulty in selling dairy products because of limited period of market opening has further increased loss as they are perishable; and cows and buffaloes need to be milked whether there is a market or not.

\section{Impact on Vegetables}

Vegetables contribute 2.6 percent to GDP and represent about 9.7 percent of the agriculture sector (CBS, 2018). In FY 2017/2018, Nepal produced 3,958,230 metric tonnes of vegetables and exported $\$ 1.23$ million worth of vegetables to India, but also imported $\$ 146.09$ million worth of vegetables in FY 2018/2019 (NRB, 2019). Vegetable exports plummeted in the first nine months of FY 2019/2020, as Nepal exported vegetables of only $\$ 13.3$ thousand compared to $\$ 10.05$ million in same period of FY 2018/2019, owing to COVID-19 disruptions. The farmers are forced to either distribute vegetables free of cost to less fortunate people or leave it decaying in the field as local agents have stopped collecting crops due to limited demand in urban areas. Farmers are unable to plant paddy and other crops, while tomatoes, onions and broccoli are left to ripen in the field. This is likely to lead to a fall in agricultural production in the future season.

\section{Impact on Poultry}

The Nepal Commercial Poultry Survey 2014-2015, conducted by the Central Bureau of Statistics found that there were around 21,000 poultry farms in Nepal, employing about 56,000 people including permanent and contract staff. Around 98 percent of farms were small-scale, rearing less than 10,000 chickens a year. They produced 114,058 metric tonnes (live weight) of chicken a year, and 1.2 billion eggs. The production of chicken and eggs increased in subsequent years. According to the Statistical Information on Nepali Agriculture 2019, the Country produced around 60,122 metric ton (net weight) of meat and more than 1.5 billion eggs in the year 2017/2018 (MoALD, 2020). As per the information reported by President of the Nepal Poultry Federation, about 0.1 million metric tons (live weight) and around 1.8 billion eggs were produced in 2019. He estimates that 1.3 million people are employed directly and 
indirectly in the sector. The lockdown has led to a significant drop in the sales of chicken and eggs, with sales down by 80 percent and 50 percent respectively. The private sector expects a shortage of chickens and eggs, because the birds will outgrow their optimum production and producers will not be able to replenish their stock.

\section{Conclusion:}

The COVID-19 pandemic, which has already infected 72,641,016 and led to the death of about $1,618,822$ individual worldwide, is extremely dangerous. The world has faced various threats before, including pandemics, yet the world does not shut down for every new infection or flu season. But, this deadly coronavirus has established immediate health and economic emergency across the globe. The Covid-19 crisis has already led to an economic fallout and labour market shock, impacting not only on supply of goods and services but also on demand (consumption and investment). The Disruptions to production, initially in Asia, have now spread to supply chains across the globe. All of the businesses, regardless of size, are facing serious consequences, especially those in the aviation, tourism and hospitality sectors, with a real threat of significant declines in revenue, insolvencies and job losses in specific sectors. Likewise, Prospects for the economy and the quantity and quality of employment are deteriorating even faster. While updated forecasts vary considerably and largely underestimate the situation; they all point to a significant negative impact on the country's national economy.

This paper thoroughly reviews on impact of COVID-19 and imposed lockdown on macroeconomic and microeconomic. Reviewing past literature showed that different sectors like remittance, tourism, labour and employment, education and agriculture has been negatively affected. The paper predicts that decreasing remittance significantly hampers the economic growth rate of Nepal. To cope with the impacts Government of Nepal should adopt various fiscal and monetary policies to limit the spread of virus and keep the national economy intact. The government must reallocate the resources to the prioritized sectors and dismantling unnecessary institutions created at all three levels of government. The uncertain impact of the COVID-19 pandemic on Nepal's social economy will magnify depending on how events unfold on three fronts; i) its dependence on tourism, trade, and foreign employment and the consequences that will propagate through the services and industrial landscape; ii) if or when the spread of the pandemic overwhelms a grossly inadequate health infrastructure and antivirals or vaccine become available and iii) Nepal's heavy geo-economic reliance on India and China, and the nature of contagion in those countries. Hence, it is important for our country to adopt a policy-mix that is able to manage both the health crisis and the livelihood. In addition to strengthening the health system, the government should be well-equipped to manage the food and energy crisis. 


\section{References}

ADB (2020). Nepal Macroeconomic Update. Asian Development Bank. Kathmandu, Nepal.

Asian Development Bank (ADB) (2020). Asian Development Outlook (ADO) 2020: What Drives Innovation in Asia? Retrieved from https://www.adb.org/publications/ asian-development-outlook-2020-innovation-asia.

Bastola, A., Sah, R., Morales, A. J. R., Lal, B. K., Jha, R., Ojha, H. C., .Pandey, B. D. (2020). The first 2019 novel coronavirus case in Nepal. The Lancet, 20(3), 279-280.

Central Bureau of Statistics (CBS) (2018). Quantity index of Agriculture Commodities (Calculation Based on CBS Data). https://cbs.gov.np/.

Central Bureau of Statistics (CBS) (2020). National Account Statistics 2020. Retrieved from: https://cbs.gov.np/.

Central Bureau of Statistics. (2019). National Economic Census Report No. 1. Central Bureau of Statistics. Kathmandu, Nepal.

Department of Customs (DoC). (2019). Foreign Trade Statistics FY 2018/19. www.customs. gov.np. https://www.customs.gov.np/en/monthlystatstics.html.

Department of Customs (DoC). (2020). Foreign Trade Statistics FY 2017/18/19/20. www. customs.gov.np. https:/ / www.customs.gov.np/en/ monthlystatstics.html.

Fegert, J. M., Vitiello, B., Plener, P. L., \& Clemens, V. (2020). Challenges and burden of the Coronavirus 2019 (COVID19) pandemic for child and adolescent mental health.

Flaxman, S., Mishra, S., Gandy, A., Unwin, H. J. T., Mellan, T. A., Coupland, H., . . Bhatt, S. (2020). Estimating the effects of non-pharmaceutical interventions on COVID-19 in Europe. Nature. Advance online publication. https://doi. org/10.1038/s41586-0202405-7.

Klimburg, A., Faesen, L., Verhagen, P. \& Philipp, M. (2020). COVID-19, information technology, and cognitive dissonance. Netherlands: Hague Centre for Strategic Studies.

Klonowska, K. (2020). The COVID-19 pandemic: Two waves of technological responses in the European Union. Netherland:Hague Centre for Strategic Studies.

Maliszewska, M., Matto, A. \& Mensbrugghbe, D.V.D. (2020). The potential impact of COVID19 on GDP and trade. World Bank Group Policy Research Working Paper No.9211.

Ministry of Agriculture and Livestock Development (MoALD) (2020). Statistical Information on Nepalese Agriculture 2074/75.

Poudel, P. B., Poudel, M. R., Gautam, A., Phuyal, S., Tiwari, C. K., . . . Bashyal, S. (2020). COVID-19 and its global impact on food and agriculture. Journal of Biology and Today's World, 9(5), 221-225.

Rubin, G. J., \& Wessely, S. (2020). The psychological effects of quarantining a city. British Medical Journal, 368, https://doi.org/10.1136/bmj.m313. 
Sophie, I. (2019). The world's top recipient of remittance, 2018. CEOWORLD Magazine.

The Kathmandu Post (2020).Government to divert Rs 136 billion budget to anti-Covid-19 measures.

The New York Times. (2020, April 30). How long will a vaccine really take? .

United Nation Development Project. (2020). Rapid Assessment of Socio Economic Impact of Covid-19 In Nepal. Available at: https:/ / www.np.undp.org/content/nepal/en/ home/library/rapid-assessment-of-socio-economic-impact.html

World Bank (2020). South Asia Economic Focus, Spring 2020: The Cursed Blessing of Public Banks. Washington, DC: World Bank. Last accessed on 25 April 2020. Retrieved from https://openknowledge.worldbank.org/handle/10986/33478

World Bank. (2020a, March 20). Educational challenges and opportunities of the Coronavirus (COVID-19) pandemic. https://blogs.worldbank.org/education/educationalchallenges-and-opportunities-covid-19-pandemic

World Health Organization. (2020). WHO Interact. https:/ / covid19.who. int/.

World Trade Organization (2020). Trade Statistics and Outlook. Last accessed on 25 April 2020. Retrieved from https://www.wto.org/english/news_e/ pres20_e/pr855_e. htm

Worldometer. (2020). https://www.worldometers.info/coronavirus/?

Wu, Y. C., Chen, C. S., \& Chan, Y. J. (2020). The outbreak of COVID-19: An overview. Journal of the Chinese Medical Association, 83(3), 217-220. https://doi.org/10.1097/ JCMA.0000000000000270

Zhu, N., Zhang, D., Wang, W., Li, X., Yang, B., Song, J., .. Tan, W. (2020). A novel coronavirus from patients with pneumonia in China 2019. The New England Journal of Medicine, 382, 723-733. https:// doi.org/10.1056/ NEJMoa2001017 